\title{
MEMBERSHIP
}

All undergraduates, graduates and post-graduates of accredited university forestry schools, or of other disciplines who are now working in a field allied to forestry or who are engaged in the practice of, teaching of, or research in a branch of forestry or related science are eligible as members of the Canadian Institute of Forestry - Institut Forestier du Canada.

If you wish further information forwarded on Institute membership or on THE FORESTRY CHRONICLE please complete and return the following form:

Secretary-Manager,

CANADIAN INSTITUTE OF FORESTRY — INSTITUT FORESTIER DU CANADA,

Box 5000, Macdonald College, P.Q.

Please forward information to: -

NAME

ADDRESS

Membership in the Institute

Subscription to THE FORESTRY CHRONICLE

Advertising in THE FORESTRY CHRONICLE

contacted by:

Print Name

Signature

(contact need not be a member of the Institute)

\section{CANADIAN FORESTRY EDUCATION}

To the man interested in Forestry as a career, Canadian schools offer education at all levels.

Professional Training

The four University Forestry Faculties, listed below, offer instruction aimed at understanding of fundamental forestry principles, and training in courses of an applied nature best suited to the needs of the forest regions they serve. Opportunities for post-graduate study are also available at the following: -

University of New Brunswick, Fredericton, N.B.

L'Université Laval, Quebec 10, P.Q.

University of Toronto, Toronto, Ontario

University of British Columbia, Vancouver, B.C.

\section{Technological and Vocational Training}

These courses are designed to provide men with an adequate knowledge of the theory and practice of Forestry, Logging and Milling so that they may, with adequate on-the-job-experience, serve as an intelligent line of communication and action between the professional forester and the forest labourer.

Two year courses in Forest Technology ore offered by: -

British Columbia Institute of Technology, Burnaby, B.C

Cambrian College, Sault Ste. Marie, Ont.

Lakehead University, Port Arthur, Ont.

Nfld. College of Trades and Technology, St. John's, Nfld.

Northern Alberta Institute of Technology, Edmonton, Alta.

Saskatchewan Technical Institute, Saskatoon, Sask.

Selkirk College, Castlegar, B.C.

Sir Sandford Fleming College, Lindsay, Ontario.

One year courses of technical training in Forestry are offered at the following schools: -

B.C. Forest Training School, North Surrey, B.C.

L'Ecole Forestière de Duchesnay, Québec, P.Q.

Maritime Forest Ranger School, Fredericton, N.B.

Ontario Forest Technical School, Dorset, Ontario.

The B.C. and Ontario schools are limited to in-service training.

For information regarding entrance requirements, courses of study, field training or facilities for specialization at any of the above, please write directly to the school in question. 